\title{
Encouraging encounters: unusual aggregations of bowhead whales Balaena mysticetus in the western Fram Strait
}

\author{
Marijke N. de Boer ${ }^{1,2, *}$, Nicole Janinhoff ${ }^{3}$, Griet Nijs ${ }^{4}$, Hans Verdaat ${ }^{1}$ \\ ${ }^{1}$ Wageningen UR, Wageningen Marine Research, 1780 AB Den Helder, The Netherlands \\ ${ }^{2}$ Seven Seas Marine Consultancy, PO Box 11422, 1001 GK Amsterdam, The Netherlands \\ ${ }^{3}$ Bergmannsweg 12, 31199 Diekholzen, Germany \\ ${ }^{4}$ Natuurpunt Studie vzw, 2800 Mechelen, Belgium
}

\begin{abstract}
The subpopulation of the bowhead whale Balaena mysticetus in the East GreenlandSvalbard-Barents Sea is endangered and until recently was believed to number in the tens. Recent studies have suggested that this subpopulation appears to be increasing. Here, we report on unusual aggregations of bowhead whales within the Fram Strait. We present opportunistic and effort-corrected observations of bowhead whales made from a small expedition vessel during cruises in June (2015-2018). Bowhead whales were sighted on 85 occasions (220-227 whales). An aggregation in $2015(\mathrm{n}=84$ whales $)$ and high numbers in $2018(\mathrm{n}=104-110)$ exceeded all previous records. The index of whale abundance was significantly higher in open water-leads (1.08-1.14 whales km-1 of survey effort) compared to areas with drift-ice $\left(0.51-0.53\right.$ whales km $\left.\mathrm{km}^{-1}\right)$. The highest abundance index was measured in deep waters where the bottom slope was relatively steep. Our findings highlight the temporal and spatial consistency of this species in areas with relatively loose ice cover (open water-leads) and steep slopes. It is unknown how global warming and resultant changes in ice-extent are going to affect bowhead whales within the Strait and whether they will find new feeding grounds due to an expanding open-ocean habitat. These slopes may become increasingly important to bowhead whales and Arctic top predators as a spring/early summer feeding ground. These relatively large numbers of bowhead whales are encouraging and can help direct future research monitoring programs to study the population ecology of these endangered whales.
\end{abstract}

KEY WORDS: Bowhead whale $\cdot$ Balaena mysticetus $\cdot$ Svalbard stock $\cdot$ Abundance $\cdot$ Platform of opportunity $\cdot$ Conservation $\cdot$ Fram Strait

\section{INTRODUCTION}

Bowhead whales Balaena mysticetus were once common in the Arctic and Subarctic Seas until they were severely depleted by commercial whaling. Currently, 4 different bowhead whale subpopulations are recognized based on their geographic distribution: (1) Bering-Chukchi-Beaufort Seas; (2) East Canada-West Greenland (3) East Greenland-SvalbardBarents Sea; and (4) Okhotsk Sea (Cooke \& Reeves

\footnotetext{
${ }^{*}$ Corresponding author: marijke.deboer@wur.nl
}

2018). The Bering-Chukchi-Beaufort Seas and the East Canada-West Greenland subpopulations appear to be increasing after having been greatly reduced by commercial whaling in the 1600 s to 1800 s (e.g. George et al. 2004, Heide-Jørgensen et al. 2007, Cooke \& Reeves 2018). The East GreenlandSvalbard-Barents Sea subpopulation (henceforth referred to as the 'Svalbard subpopulation') was originally by far the most abundant in an area that extended eastward from East Greenland, including

๑ The authors 2019. Open Access under Creative Commons by Attribution Licence. Use, distribution and reproduction are unrestricted. Authors and original publication must be credited. 
the Greenland, Barents, and Kara Seas. The preexploitation abundance based on catch data has been estimated between 24000 and 100000 whales (Allen \& Keay 2006). They were the first Arctic whale species to be exploited by whalers around Spitsbergen (Svalbard) in 1611 (Ross 1993, Allen \& Keay 2006). Within the Northeast Atlantic alone, an estimated 91000 whales were harvested (Ross 1993), which depleted the Svalbard subpopulation to near extinction, and its current status is regarded as Endangered according to the IUCN (Cooke \& Reeves 2018).

There is no quantitative estimate of the current Svalbard subpopulation size. During the second half of the 20th century, bowhead whales were infrequently observed in the former range of the Svalbard subpopulation, and the majority of sightings were made in the Svalbard-Franz Josef Land area (Moore \& Reeves 1993). These Franz Josef Land records included 2 quite large winter aggregations, one of several tens and the other of about 66 whales in 1983 (Belikov et al. 1989). The Svalbard subpopulation has been reported to be very small (Wiig et al. 2010) with estimates of a 'few tens' reported between 1987 and 1989 (Christensen et al. 1992). Wiig et al. (2010) summarized 46 sightings of bowhead whales from Svalbard (between 1940 and 2009). Most observations involved 1 or 2 whales, but 1 group of at least 7 whales was observed in 2006. In the Greenland Sea, very few bowhead whales were recorded during 1940-2004 (Gilg \& Born 2005). That study documented 23 sightings, including one probable sighting of 10 individuals in 2003. Seven sightings (totalling 20 whales) were reported in the Greenland Sea in April 2006 (Wiig et al. 2007). Thirteen sightings (totalling 17 bowhead whales) were recorded during extensive ship- and aircraft-based surveys off Northeast Greenland (summers of 2006-2008, Boertmann et al. 2009).

Recent studies have collectively suggested that the Svalbard subpopulation seems to be increasing (Joiris 2012, Boertmann et al. 2015, Vacquié-Garcia et al. 2017). During aerial surveys for the walrus Odobaenus rosmarus in Northeast Greenland in August 2009 (in an area known as the Northeast Water Polynya), Boertmann et al. (2015) made 7 observations of single bowhead whales and recorded 2 whales during transit. These authors furthermore suggested that more than 100 bowhead whales (coefficient of variation $[\mathrm{CV}]=0.61,95 \% \mathrm{CI}=32-329$ ) might have occupied the Northeast Water Polynya in 2009. Vacquié-Garcia et al. (2017) carried out an aerial survey north of the Svalbard Archipelago in
August 2015 and reported a total of 15 bowhead whale sightings involving 27 whales. These authors suggested a conservative estimate of $343(\mathrm{CV}=$ 0.488, 95\% CI = 136-862) bowhead whales within said study area in 2015. Results of recent acoustic surveys in the Fram Strait (the passage between Svalbard and Greenland) show that bowhead whales use this as a wintering ground, with probably more whales in this (Svalbard) subpopulation than previously thought (Moore et al. 2012, Stafford et al. 2012, 2018).

Whaling records have provided some historic background regarding the seasonal migration of bowhead whales (Moore \& Reeves 1993, Lydersen et al. 2012). These records highlighted that those whales hunted in waters northwest of Svalbard (adult males and females without calves), migrated southwestward by late spring (in April and May) towards East Greenland, while others moved north from Svalbard into the receding pack ice. Recently, a satellite tracking study of a female bowhead whale between April and December 2010 showed a migration route consistent with the migration patterns based on early whaling records (Lydersen et al. 2012).

During annual expedition cruises carried out in June (2015-2018) by commercial tour operators (Oceanwide Expeditions and Inezia Tours), bowhead whale sightings were recorded in the western Fram Strait. Observations of bowhead whales from the Fram Strait are of considerable interest given the status of this Endangered subpopulation. Here we describe the group composition of bowhead whales, their behaviour and their association with sea ice and bathymetric features. Finally, the 2018 cruise results are used to estimate indices of abundance (number of whales per $\mathrm{km}$ unit of effort).

\section{MATERIALS AND METHODS}

\subsection{Study area}

Since 2014, commercial operator Inezia Tours has chartered polar expedition operator Oceanwide Expeditions to undertake annual wildlife expeditions in late May/June from the Netherlands, via Fair Isle and Jan Mayen to Svalbard, crossing the Greenland Sea and visiting the edge of the pack ice in the western Fram Strait (Fig. 1). The expedition cruise-vessel, the $89 \mathrm{~m}$ long MV 'Plancius', offers outside viewing points from several decks. The majority of sightings were typically made from the outside bridge-wings 


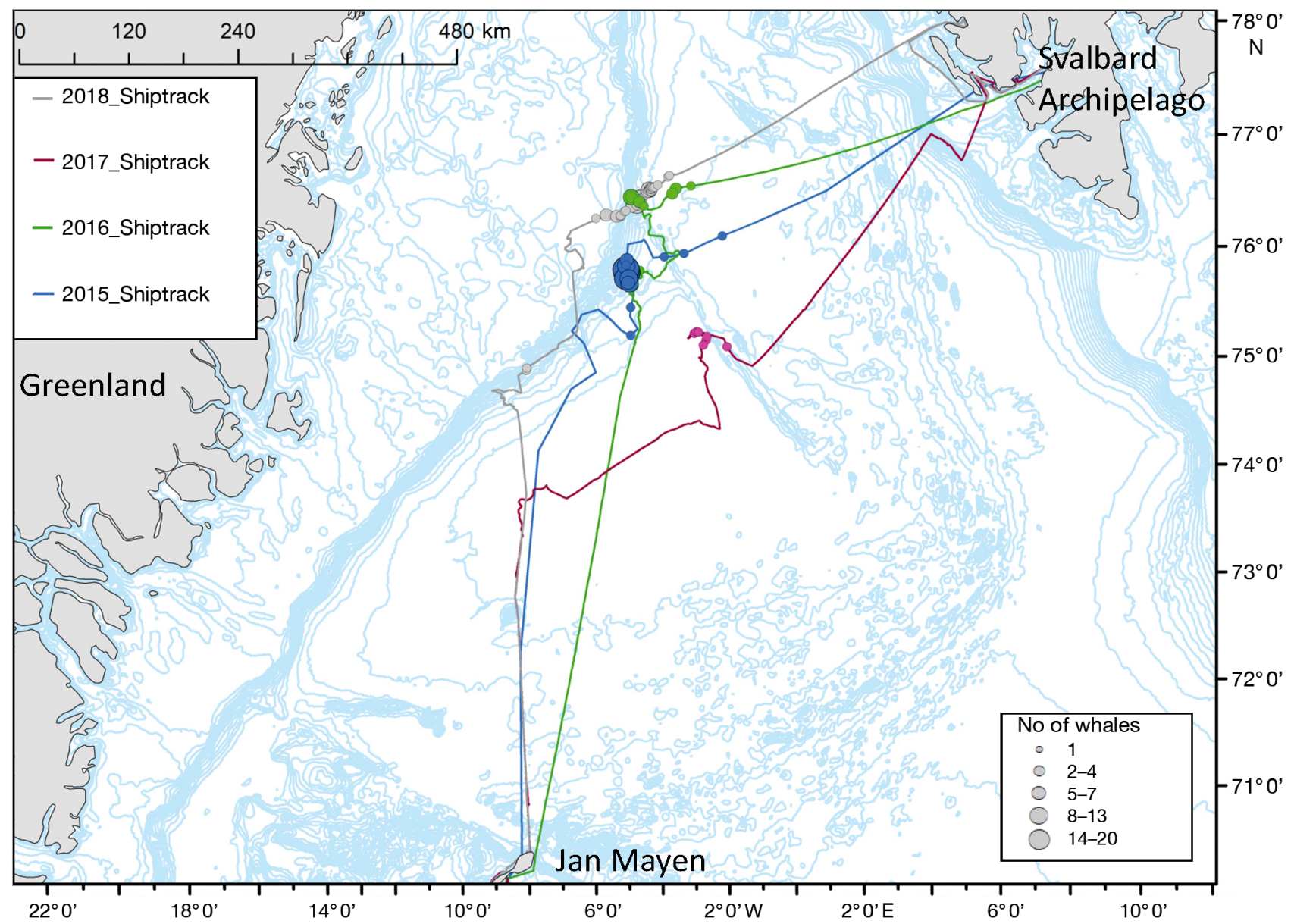

Fig. 1. Different cruise tracks (lines) of the MV 'Plancius' between Jan Mayen and Svalbard together with the positions (circles) of bowhead whale sightings between 2015 and 2018

(13 $\mathrm{m}$ above sea level). In 2018, systematic observations were carried out from the bridge-wings and the forward deck (10.4 $\mathrm{m}$ above sea level).

No bowhead whales Balaena mysticetus were encountered in 2014. The MV 'Plancius' took a more westerly route in 2015, covering the steep slope waters of the Western Fram Strait, where on 8 June 2015 the first bowhead whales were observed. In 2016-2018, the cruise re-visited this general area, and bowhead whales were observed in each of these $3 \mathrm{yr}$.

\subsection{Opportunistic observations}

In 2015, the estimation for the total number of bowhead whales encountered was based on observations made by 7 experienced whale watching specialists (including G. Nijs). These experienced observers in dependently counted the number of whales surrounding the vessel during several point counts. Photographs were taken and GPS positions were obtained from the vessel's GPS (Furuno RD-30). During the 2016-2017 cruises, observers (M. de Boer, H. Verdaat, N. Janinhoff - all experienced with carrying out cetacean line-transect surveys in Europe and the high Arctic) recorded each bowhead whale sighting, together with details on environmental conditions. Photographs were taken of each encounter, and a GPS position was obtained every minute using a Garmin GPS (GPSMAP76CSx).

\subsection{Effort-corrected observations}

In 2018, systematic (effort-corrected) watches were carried out by 3 dedicated observers (M. de Boer, $\mathrm{H}$. Verdaat, N. Janinhoff), with one covering portside, one covering starboard and one on break. Whilst on watch, the following data were collected: vessel position, vessel course, vessel speed, swell height (low $\leq$ $2 \mathrm{~m}$, medium 3-4 $\mathrm{m}$, and large $>4 \mathrm{~m}$ ), visibility (estimated by eye: poor $<1 \mathrm{~km}$, moderate $1-5 \mathrm{~km}$, and 
good $>5 \mathrm{~km}$ ), ice category and Beaufort Sea state (BSS). The following ice categories were used: (1) fast ice (100\% ice); (2) very close drift-ice $(90-100 \%)$; (3) close drift-ice $(70-90 \%) ;$ (4) open drift-ice $(40-70 \%) ;(5)$ very open drift-ice $(10-40 \%)$; and (6) open water $(0-10 \%)$. During meal times, a constant watch was ensured by 1 observer. GPS positions were obtained every minute using a Garmin GPS (GPSMAP76CSx). The following information regarding observed whale behaviour was noted: travel speed (slow, moderate, fast), resting, feeding, interaction with boat, association with seabirds and other behaviour events such as arching of tailstock and fluking. The group composition (presence of young) was recorded, and group size was estimated (minimum and maximum number of whales). In areas with numerous whales the minimum estimate was based on the number of fluking whales. The presence of any young was defined by comparing their size to that of the larger whales within a group (bowhead whales $<7 \mathrm{~m}$ long are regarded as calves and those whales 7-13 m long as sub-adults; Koski et al. 1993). Photographs were taken with digital cameras (Canon 7D with Canon 70-200 mm f2.8, 7D-mark II with Canon $300 \mathrm{~mm}$ lens f2.8 fitted with a 1.4 converter). The relative bearing (using the clock system, where 12 o'clock represents the heading of the bow) and distance to each sighting was estimated by eye. The latter information helped with the exclusion of any re-sightings. Vessel speed was mostly constant (10 knots) and a steady course was kept when transiting through open water.

\subsection{Data sources and processing}

Only observations made by experienced observers or sightings supported by photographic documentation were considered as 'definite records' of bowhead whales. Observations reported by passengers were considered likely to be genuine bowhead whale sightings according to the description details provided and were classified as 'probable records'. If a reported observation was not sufficiently detailed or was unclear, it was characterized as a 'possible record' and not included in any further analysis. In general, bowhead whales were identified by their large size and proportionally large head, dark coloured back, lack of dorsal fin and v-shaped blow. In addition, we assume that there were no North Atlantic right whales Eubalaena glacialis in the area that could be confused with distant bowhead whales.

Effort-related records (definite/probable records) collected in 2018, during BSS 0-4, moderate or good visibility $(\geq 1 \mathrm{~km})$ and low swells $(\leq 2 \mathrm{~m})$ were used for data analysis. GPS positions were imported into ArcGIS v10.2.1 (with the following coordinate system: Transverse_Mercator, Central_Meridian: -5.0 , Latitude of Origin: 77.77, Linear Unit: Meter, Geographic Coordinate System: GCS_WGS_ 1984). A grid with a resolution of $10000 \times 10000 \mathrm{~m}\left(10 \mathrm{~km}^{2}\right.$ grid cells) was created. The latitude and longitude were assigned to the center of each grid cell when determining the mean water depth. The index of abundance (relative abundance) was measured and expressed as the number of individuals per $1 \mathrm{~km}$ survey effort (whales $\mathrm{km}^{-1}$ ). Bathymetry data (average seabed depth) were sourced from the General Bathymetric Chart of the Oceans data (GEBCO 2014) at a resolution of 30 arc seconds $(1 \mathrm{~km})$ for the wider region of the Greenland Sea. Ice charts were sourced from the Norwegian Meteorological Institute (Norwegian Ice Service 2018).

We employed statistical tests using the statistical package PASW for Windows (SPSS, version 21). To determine whether the whales were concentrating in waters with particular ice categories, a Chi-squared goodness of fit test was used to investigate whether the observed number of whales differed from an expected Poisson distribution. This was also investigated using the abundance index of whales (whales $\mathrm{km}^{-1}$ ) derived for effort-corrected data only (collected in 2018).

\section{RESULTS}

During the 2015-2018 cruises, 85 sightings of bowhead whales Balaena mysticetus were made in total (excluding re-sightings but including 6 sightings classed as 'probable'), involving 220-227 individuals. A summary for each cruise year is provided below. On average, the bowhead whales occurred in water depths of $1943 \mathrm{~m}$ (SD: $819 \mathrm{~m}$, range: 218-3718 m). Of all sightings, more than half occurred in open water $(54.5 \%)$, which was more often than expected $\left(\chi^{2}=\right.$ 96.78, $\mathrm{p}<0.001$ ).

\subsection{Opportunistic observations (2015-2017)}

On 8 June 2015, an unusually large aggregation of an estimated 84 bowhead whales was observed within a relatively small area $\left(32 \mathrm{~km}^{2}\right)$ (Fig. 2). The whales were in an open water-lead, and several whales were actively skim-feeding at the surface. 


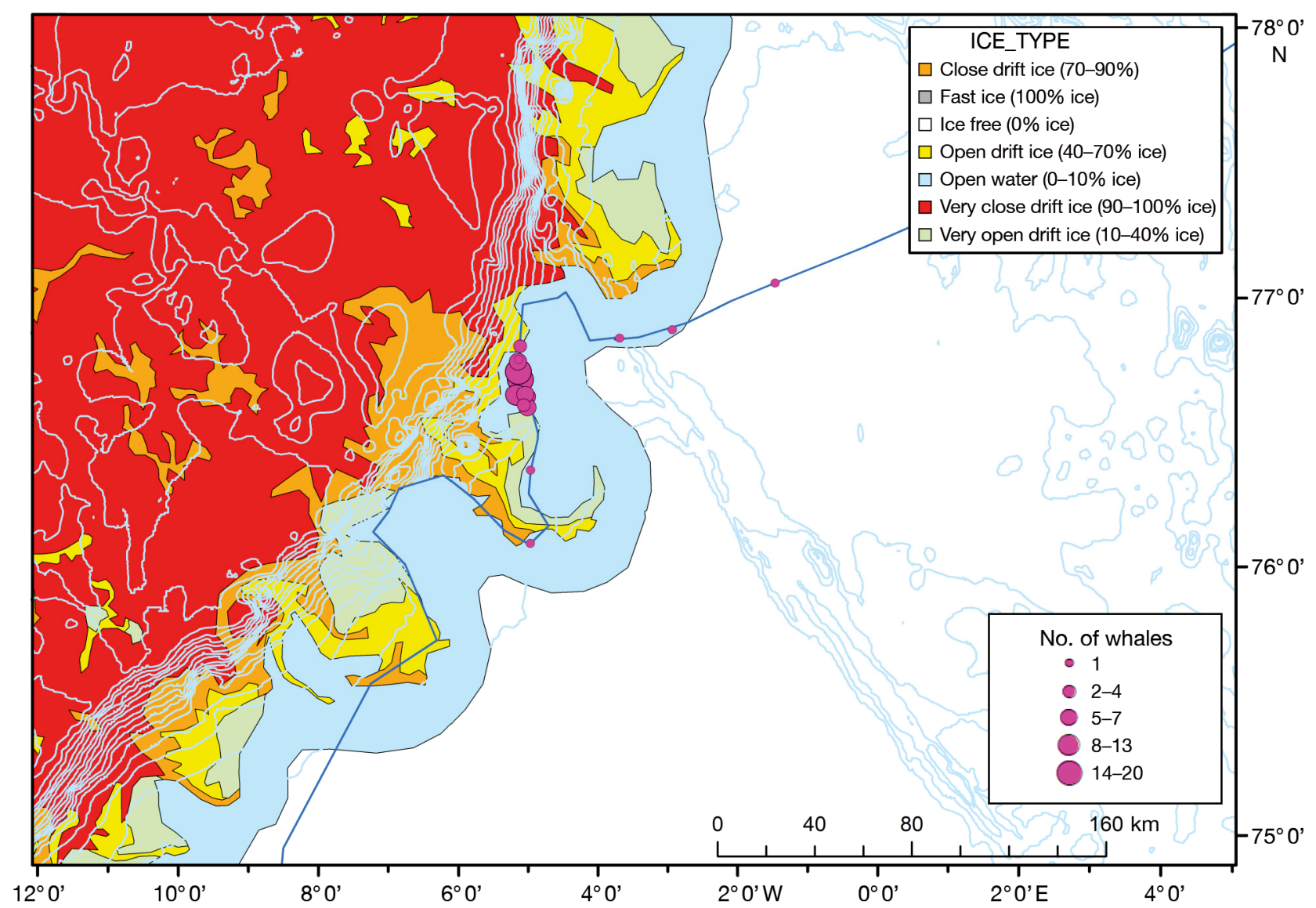

Fig. 2. Location of bowhead whales on 8 June 2015 in relation to the ice edge (ice chart for 8 June 2015 provided by the Norwegian Meteorological Institute (NMI, Norwegian Ice Service 2018)

They alternated their skim-feeding bouts with shallow dives, surfacing again after 2-5 min. Most of the whales were present in open water, near the edge of open drift-ice (see Fig. S1A-C in the Supplement at www.int-res.com/articles/suppl/n039p051_supp.pdf), although several whales were surfacing within driftice. No calves or juveniles were detected with certainty. The following morning, 3 more sightings with bowhead whales occurred whilst the vessel was transiting through open water to Svalbard. In total, 15 point-counts were carried out on 8 and 9 June 2015, involving 89 whales. The whales were recorded in waters of 1184-3192 m depth. However, during the peak period (22:00-01:00 $\mathrm{h}$ local time [UTC $+2 \mathrm{~h}$; LT]), the whales were recorded in waters of 1184-1577 m depth.

In 2016, over a period of $2 \mathrm{~d}$ with calm conditions (BSS 2) and good visibility, 9 sightings involving 17 bowhead whales were made in total (Fig. 3). The whales were recorded in waters of 1196-2956 m depth. On 5 June 2016, 2 bowhead whales were briefly observed in a narrow open water-lead in very close drift-ice without creating obvious blows. Another whale was observed when a large head surfaced amongst ice floes. The next morning, a group of 5 bowhead whales, all believed to be adults, surfaced within an open water-lead at the edge of very close drift-ice. Two more bowhead whales were seen traveling away from the vessel and heading for the pack-ice. About $1 \mathrm{~h}$ later, 2 adult bowhead whales were regularly surfacing (up to 18 times over $10 \mathrm{~min}$ ) within open water but no fluking was observed.

On 5 June 2017, in calm sea conditions (BSS 2) and with good visibility, 7 bowhead whales were observed in total (Fig. 4). The whales were recorded in waters of 2369-3718 m depth. The first whale was seen in a small open water-lead heading towards drift-ice where hundreds of harp seals Pagophilus groenlandicus were hauled out. A second and a third whale were seen briefly surfacing slowly along the ice-edge. More bowhead whales were observed swimming slowly at the surface and fluking (Fig. S1G). Another skim-feeding whale was seen swimming slowly with its mouth open 


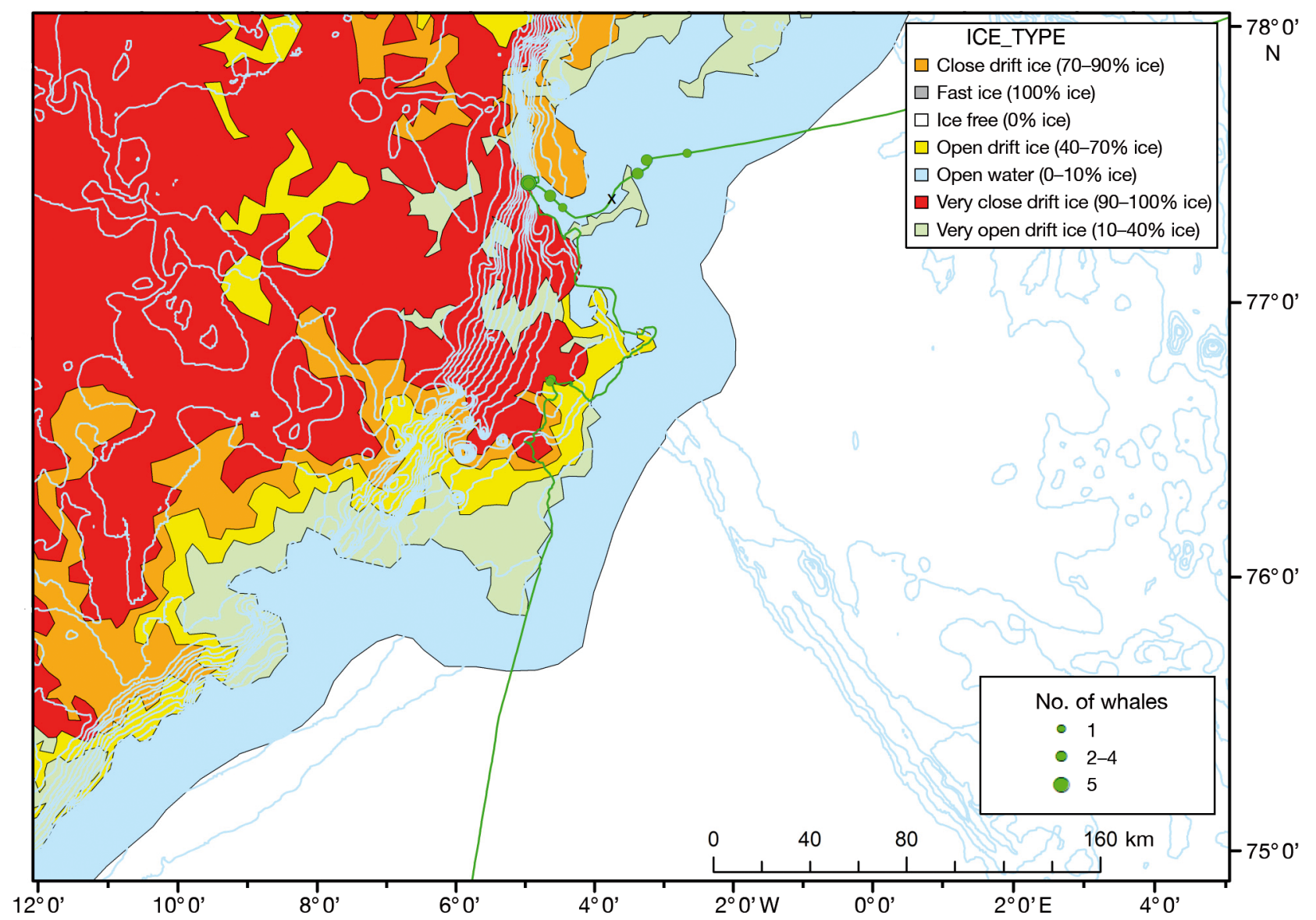

Fig. 3. Location of bowhead whales on 5-6 June 2016 in relation to the ice edge (ice chart for 6 June 2016 provided by the NMI). $x$ : position of a pod of killer whales on 6 June 2017

(observed amongst very open drift-ice, Fig. S1F). Northern fulmars Fulmaris glacialis were associating with the whale, apparently feeding on peeling skin or parasites on the whale's skin, with 1 bird briefly landing on the muscular bulge of the blowholes (Fig. S1D-E). A probable bowhead whale was reported by a passenger while the vessel was in transit to Svalbard.

\subsection{Effort-corrected observations (2018)}

On 31 May 2018, the first bowhead whales were reported by passengers (Fig. 5). The next morning was foggy, and effort-corrected watches did not commence until conditions improved at noon. At 12:15 h (LT), the first bowhead whale was spotted when the vessel reached a stretch of drift-ice. A wide-spread group of at least 4 bowhead whales then surfaced within a large area of open water. Another 8 bowhead whales were observed, including one sub- adult, when the vessel approached open drift-ice. The vessel spent the next $1.5 \mathrm{~h}$ within very open drift-ice, and one additional bowhead whale surfaced between large ice-floes (Fig. S1H). At least another 9 bowhead whales surfaced right along the ice-edge or just within the open drift-ice in subgroups of 1-5 individuals. The vessel then reached a wide open water-lead and steamed for $1.5 \mathrm{~h}$ at a speed of 10 knots. During this period, 43-47 bowhead whales (excluding re-sightings) were recorded in sub-groups of 1-7 individuals. Most whales were traveling, showing distinct V-shaped blows and fluking regularly. Bowhead whales were also seen in very close proximity of drift-ice. Upon leaving the ice, 28-29 bowhead whales were seen in open water, in sub-groups of 1-5 individuals (including 1 subadult). The vessel then reached very open drift-ice, but it was not until the vessel was in open water that the last 2 bowhead whales were recorded. In summary, during the effort-corrected watch $(7.5 \mathrm{~h}), 52$ bowhead whale sightings were made in total, involv- 




Fig. 4. Location of bowhead whales on 5 June 2017 in relation to the ice edge (ice chart for 5 June was not available, so the ice chart for 4 June 2017 was provided by the NMI)

ing 104-110 whales. The whales were recorded in waters of 218-2792 $\mathrm{m}$ depth. The overall index of abundance of bowhead whales was $0.88-0.93$ whales $\mathrm{km}^{-1}$ (7.5 $\mathrm{h}$ watch). The highest abundance index for bowhead whales was measured in deep waters, where the bottom slope was relatively steep (Fig. 6). During those periods when the vessel steamed through open water-leads (average speed of 10.6 knots), the index was 1.08-1.14 whales $\mathrm{km}^{-1}$, and when the vessel was transiting slowly through open drift-ice, the index was significantly lower $(0.51-0.53$ whales $\left.\mathrm{km}^{-1} ; \chi^{2}=10.15, \mathrm{p}=0.006\right)$.

\section{DISCUSSION}

The number of bowhead whales Balaena mysticetus observed during the cruises (85 sightings involving 220-227 bowhead whales), specifically the unusual aggregation observed in 2015 ( $\mathrm{n}=84$ whales) and the high numbers in 2018 ( $\mathrm{n}=104-110)$, exceed all previous published observations. No calves were observed, and sub-adult whales were only seen on 2 occasions. Young bowhead whales are rarely encountered in the Fram Strait and Greenland Sea: a young bowhead whale was observed off the Blosseville Coast in East Greenland on 25 June 2008 (Boertmann et al. 2009), and a calf was reported during an aerial survey on 26 July 2009, close to the ice-edge in the coastal areas of NE Greenland (Boertmann \& Nielsen 2010).

The largest groups observed in the present survey consisted of 7 and 10 whales, but some of these groups were part of a total of 84 bowhead whales observed within 1 open water-lead on 8 June 2015. Such unusual aggregations were not witnessed in later cruises, although at least 104 bowhead whales were recorded during $7.5 \mathrm{~h}$ of transit on 1 June 2018. Only old records from Franz Josef Land include sightings involving such large aggregations, one involving about 66 animals in the winter of 1983 (Belikov et al. 1989, Moore \& Reeves 1993).

Bowhead whales occurred more often in open water than expected, both in 2018 and overall 


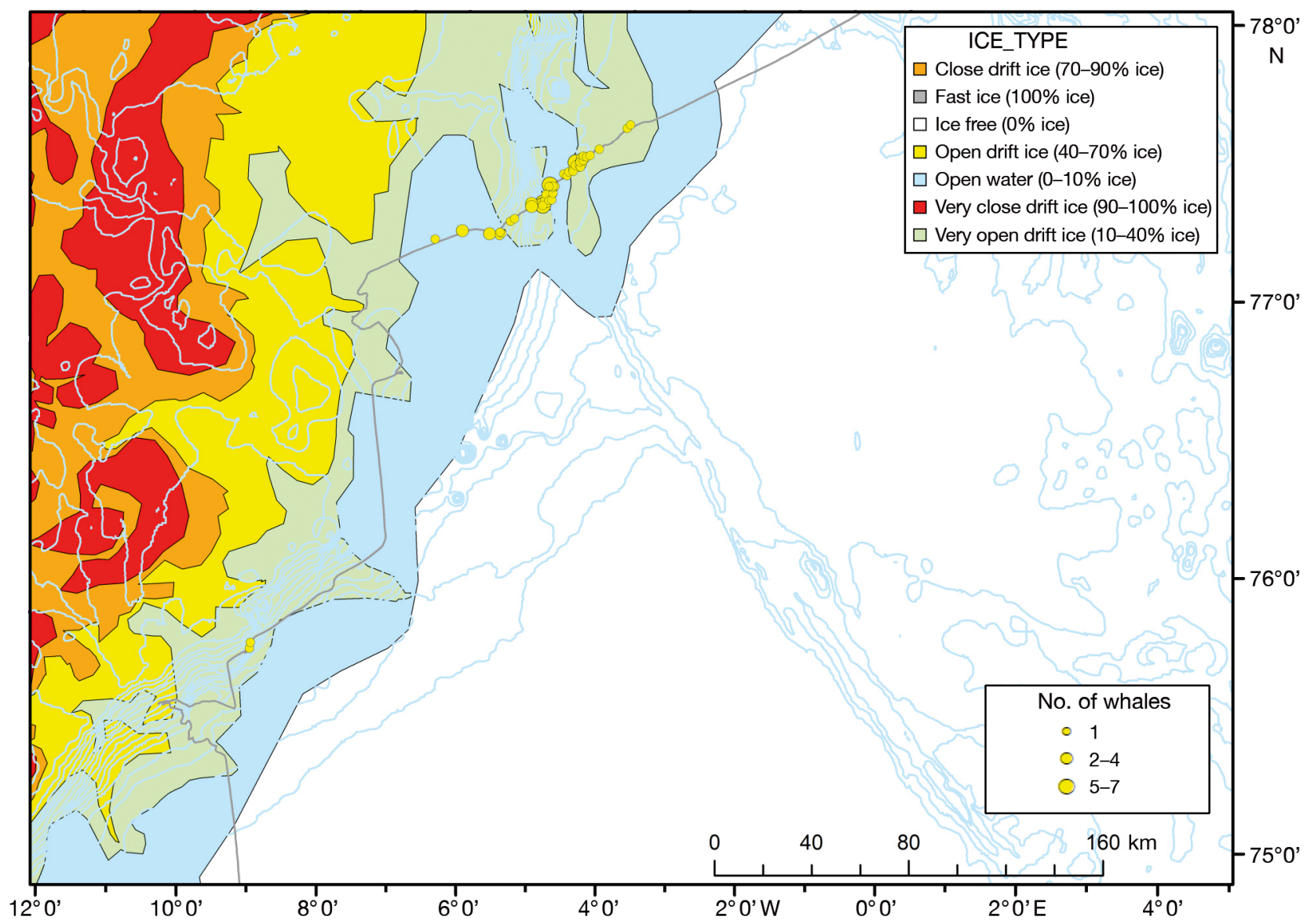

Fig. 5. Location of bowhead whales on 31 May and 1 June 2018 in relation to the ice edge (ice chart for 1 June 2018 provided by the NMI)

(2015-2018). In 2018 alone, the index of whale abundance was also found to be significantly higher in open water-leads (1.08-1.14 whales $\mathrm{km}^{-1}$ ) compared to waters with open drift-ice (0.51-0.53 whales $\mathrm{km}^{-1}$; $\left.\chi^{2}=10.15, \mathrm{p}=0.006\right)$. This difference may be explained by the fact that open drift-ice partially limits the view, making it more difficult to detect slowmoving or skim-feeding bowhead whales that do not produce a visible blow. Nevertheless, bowhead whales are known to move from one foraging area to another, sometimes crossing ice-packed areas, where they apparently do not feed (Heide-Jørgensen et al. 2003). One bowhead whale was seen up to $42 \mathrm{~km}$ from the ice-edge (Fig. 2). A tagged female bowhead tracked by Lydersen et al. (2012) associated mainly with open water, never occurred in areas with ice cover above $65 \%$ and was recorded $180 \mathrm{~km}$ from the ice-edge. Off Svalbard, bowhead whales occupy areas deep within the pack-ice during winter, as discovered based on acoustic data (Stafford et al. 2012, 2018). The affiliation between bowhead whales and sea-ice has also been explored off West Greenland: whales in that area preferred high ice cover (>65\%) with thick first-year ice and open water (Ferguson et al. 2010). This ice preference was considered to relate to the avoidance of predation by killer whales, which tend to stay away from thick ice (Matthews et al. 2011). In the present study, some bowhead whales were seen in close drift-ice (70-90\% ice cover); however, the majority of whales were observed in open water-leads and adjacent to or within areas of open drift-ice, where they might be more at risk of being attacked by killer whales.

Other studies report bowhead whales in waters $\leq 300 \mathrm{~m}$ depth off East Greenland, where a shallow habitat offers optimal feeding opportunities in August (e.g. Boertmann et al. 2009, 2015). In the present study, the highest abundance index for bowhead whales was recorded in deep waters (average depth $2000 \mathrm{~m}$ ), where the bottom slope was relatively steep (calculated from depth values: between 15 and $30^{\circ}$; Fig. 6). The whale tracked by Lydersen et al. (2012) also showed a preference to stay over areas with steeply sloping bottom topography. Such bathy- 


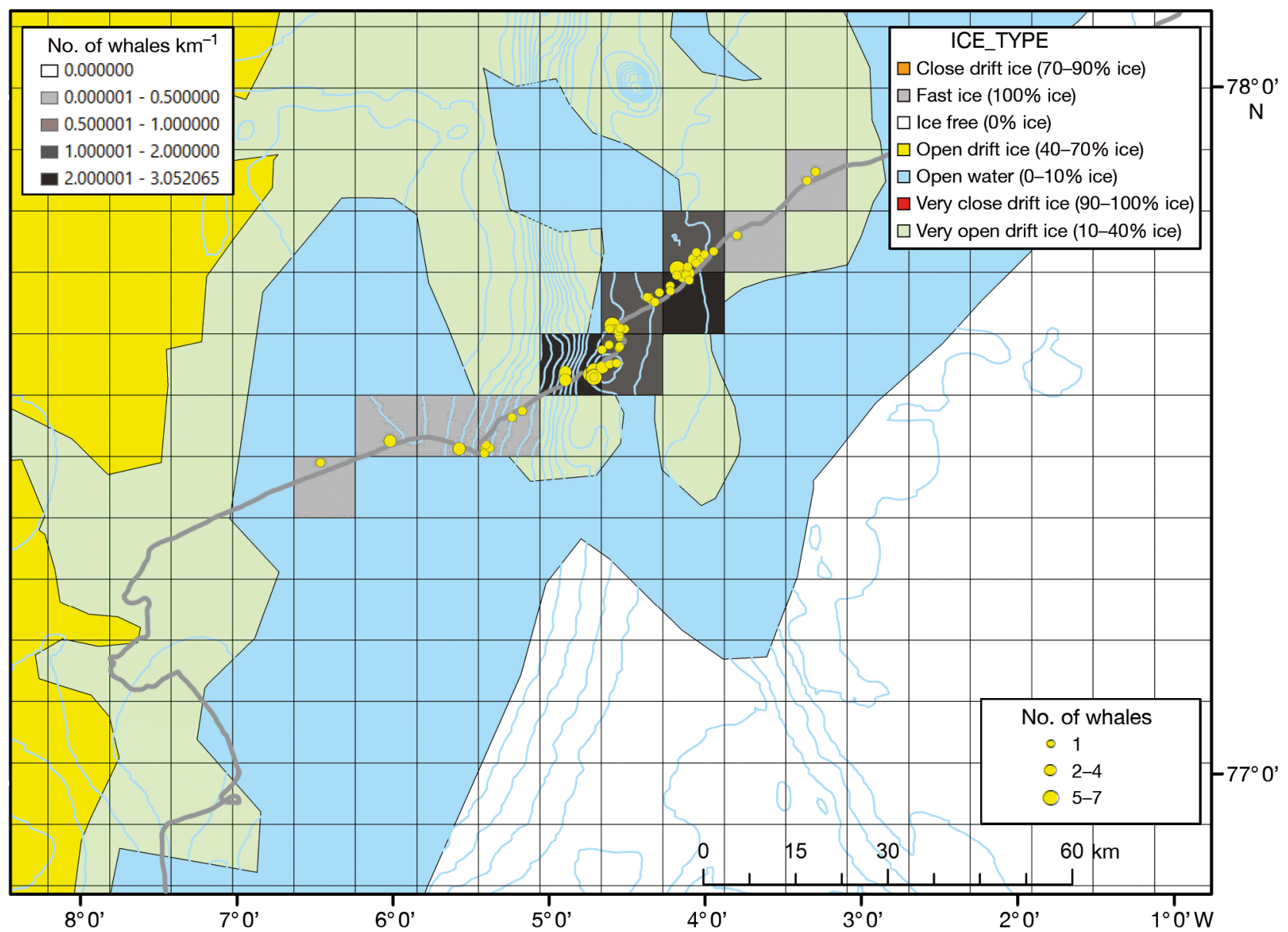

Fig. 6. Indices of abundance in relation to steep slopes (blue lines) and ice edge (ice chart for 1 June 2018 provided by the $\mathrm{NMI}$, calculated as the number of bowhead whales $\mathrm{km}^{-1}$ in 2018 . The cruise track is shown in grey

metric features steer upwelling, and the resulting increase in productivity can cause favourable foraging conditions (Miller 2003). The simultaneous occurrence of drift-ice and steep bathymetric features in the present study may have created optimal feeding conditions for the whales in late May/early June. Indeed, feeding behaviour, most notably skim-feeding, was observed during most cruises. Slow swimming with very little forward-directed movement and shallow dives (which can be indicative of feeding) were also frequently observed.

Some whales appeared very sensitive or shy and were traveling away from the vessel in the direction of the nearest drift-ice. Such avoidance behaviour was often accompanied by distinct V-shaped blows and occasional fluking. Whales were also observed swimming just under the surface, leaving a trail of fluke prints whilst heading for the nearest ice. Nonetheless, bowhead whales would occasionally surface right next to the vessel without showing avoidance behaviour. The MV 'Plancius', originally designed for the Royal Netherlands Navy to carry out seismographic surveys, was built with a diesel-electric engine (Stork-Werkspoor Diesel 3x $904 \mathrm{~kW}$ ) and a low noise-level, submarine-type propeller holding 6 blades (propeller, type 1 lip, 6 blades, clockwise rotation bronze). The ship's low noise levels likely enhanced our chances of observing whales prior to avoidance movements, since ship noise may cause avoidance behaviour: During a recent survey off North Svalbard, using a helicopter and 2 icebreaking ships, 27 bowhead whales were observed from the helicopter, but no observations were made from the vessels (Vacquié-Garcia et al. 2017).

The number of cruise-vessels operating within the Arctic is steadily increasing, resulting in a growing number of sightings involving Arctic whales. Such sightings are readily reported to online databases, such as http://observation.org or the Svalbard Visitors' Marine Mammal Sightings Database held by the Norwegian Polar Institute (e.g. Vacquié-Garcia et al. 2017). Although this provides an increasing number of 
data sets, opportunistic records of bowhead whales are lacking documentation of actual sighting effort. The present study is a first step in filling that gap by supplying effort-corrected data. Cruise-vessels have been shown to be suitable 'Platforms of Opportunity' (POs), whereby the platform is opportunistic, but the research is dedicated (i.e. effort-corrected; Williams 2003, De Boer 2013). The main problem of cruisevessels acting as a PO is that their routes are not determined by the research design but are often dependent on navigation or influenced by scenery. Therefore, basic statistical design requirements are not met (Viddi et al. 2010). However, the collection of data from a cruise-vessel is by far the most affordable way to collect data on cetacean distribution, relative abundance and behaviour (e.g. Evans \& Hammond 2004, De Boer 2013). PO-based data can also be the only available information about cetaceans in under-recorded areas; these data are particularly important when an abundance index for conservation or management purposes is needed, but no accurate estimates of abundance are available (e.g. De Boer et al. 2016).

Significant numbers of bowhead whales were also recently reported during 2 aerial surveys in the marginal ice zone north of the Svalbard Archipelago (Vacquie-Garcia et al. 2017) and in the Northeast Water Polynya in northeast Greenland (Boertmann et al. 2015). These findings together with data from the present study and other sources support the hypothesis that the Svalbard subpopulation of bowhead whales is probably larger than previously thought and that this is not just a result of increased search effort (Gilg \& Born 2005, Boertmann et al. 2009, 2015, Boertmann \& Nielsen 2010, Wiig et al. 2010, Joiris 2012, Vacquié-Garcia et al. 2017). On the other hand, various whale research expeditions (in 2006-2008 and 2010) between east Greenland and Svalbard, as well as a polar bear (Ursus maritimus) survey (in 2004) recorded very few bowhead whales (Wiig et al. 2007, 2010, Aars et al. 2009, Kovacs et al. 2011, Lydersen et al. 2012). These sparse observations may have been due to a patchy distribution pattern of the bowhead whales but may also have been influenced by the species' tendency to avoid noisy, ice-breaking research vessels. Bowhead whales may have migrated into this area from other subpopulations (Bering-ChukchiBeaufort Seas or East Canada-West Greenland) over the past decade (Boertmann et al. 2015, Stafford et al. 2018). Such migrations may have been facilitated by the reduction in sea-ice (e.g. Heide-Jørgensen et al. 2007). It is unclear how an expanding open-ocean habitat is influencing the migration of bowhead whales, but there are apparent increasing trends in some other baleen whale populations (Moore 2016). A variable distribution of the species within the Svalbard subpopulation also seems likely, but further studies are needed to confirm the degree of inter- and intraannual variability in bowhead whale distribution (Vacquié-Garcia et al. 2017).

Global warming and the resulting reductions in seaice extent represent a serious threat to ice-associated species (e.g. Laidre et al. 2015). In the case of bowhead whales, distributional shifts in tandem with climate variation have been documented in the past. Dyke et al. (1996) demonstrated that the distribution range of bowhead whales expanded and contracted abruptly several times over the last 10500 yr. Recently, a series of extralimital records of bowhead whales have been reported well outside the Arctic Circle in the North Atlantic (e.g. De Boer et al. 2017), and these could be early signs of distributional changes taking place. The timing and extent of primary production are strongly related to the patterns of ice-formation in autumn and ice-recession in spring. Extensive ice cover cools the water column during the critical spring period, when zooplankton graze on phytoplankton. By contrast, reduced sea-ice allows solar energy to warm and stratify the water column earlier, resulting in a premature phytoplankton bloom, which disrupts the interaction between phytoplankton and their zooplankton grazers that ascend from depth at specific times of the year (e.g. Hunt et al. 2002, Hansen et al. 2003, Bluhm \& Gradinger 2008). Such a mismatch could have a negative influence on bowhead whales simply by less food being available. However, local increases in primary production due to reduced sea-ice cover have surprisingly resulted in improved body condition of bowhead whales in the Beaufort Sea (George et al. 2015). In the latter study, the improved body condition was correlated with reductions in sea ice and other environmental factors (e.g. upwelling) which favoured an increase in zooplankton grazers. However, it is not known how local changes in ice-extent are going to affect bowhead whales in the Fram Strait, or how successful they will be in finding new feeding grounds due to an expanding open-ocean habitat. Offshore slopes may become increasingly important to bowhead whales within the Fram Strait during spring and early summer. Further studies are necessary to predict the importance of these offshore slopes as spring feeding habitats for bowhead whales and Arctic top predators.

Vacquié-Garcia et al. (2017) highlighted the need to develop routine monitoring methods for bowhead whales, given the recent rapid declines in sea-ice 
within the Arctic. The present study highlights that vessels with a low noise output, such as the MV 'Plancius', can be used as a suitable PO to study ice-associated whales. PO data complement standard survey designs and can help to fill some of the gaps (in terms of space and time) in survey coverage (e.g. Williams et al. 2006, De Boer 2013, De Boer et al. 2016, 2018). Furthermore, we encourage all cruise operators to upload their observations to the available online databases (e.g. http://obser vation.org) to help in the collection and documentation of whale sightings. The relatively large numbers of bowhead whales we report here are encouraging and will hopefully help direct future research monitoring programs to enhance our knowledge of the population ecology of the Endangered bowhead whale, ultimately contributing to this species' conservation.

Acknowledgements. We thank all the observers from Natuurpunt Belgium and Vogelbescherming Nederland and in particular co-observers Karen Mulders and Beate Thier. We also thank Olivier Dochy, Bart De Knegt, Gerald Driessens, Arjen Drost, Morten Joergensen, Meghan Kelly, Wesley Overman, Adam Walleyn and Pierre van der Wielen for their observations, Cor Visser, Carlos De Wagter and Bart Van Gelder for contributing photographs, and Lynn Woodworth for her support. Special thanks to Pieter van der Luit (Inezia Tours/PolarXL) for designing the cruises and for his support and enthusiasm. Of equal importance has been the support and goodwill of Captain Evgeny Levakov, Captain Alexey Nazarov, the crew of the MV 'Plancius' and all expedition leaders. Many thanks also to Femke Wolfert, Troels Jacobsen and Oceanwide Expeditions for their logistical support and Natuurpunt for financial support. We are grateful to the Norwegian Meteorological Institute, which provided the Ice Charts. And finally, we thank the anonymous reviewers whose efforts greatly improved this manuscript.

\section{LITERATURE CITED}

Aars J, Marques TA, Buckland ST, Andersen M, Belikov S, Boltunov A, Wiig $\varnothing$ (2009) Estimating the Barents Sea polar bear subpopulation size. Mar Mamm Sci 25:35-52

Allen RC, Keay I (2006) Bowhead whales in the eastern Arctic, 1611-1911: Population reconstruction with historical whaling records. Environ Hist 12:89-113

Belikov SE, Gorbunov YA, Shilnikov VI (1989) Distribution of Pinnipedia and Cetacea in Soviet arctic seas and the Bering Sea in winter. Sov J Mar BioI 15:251-257

Bluhm BA, Gradinger R (2008) Regional variability in food availability for Arctic marine mammals. Ecol Appl 18(Supplement):S77-S96

* Boertmann D, Nielsen RD (2010) A bowhead whale calf observed in northeast Greenland waters. Polar Rec 46: 373-375

Boertmann D, Merkel F, Durinck J (2009) Bowhead whales in East Greenland, summers 2006-2008. Polar Biol 32: 1805-1809
Boertmann D, Kyhn LA, Witting L, Heide-Jørgensen MP (2015) A hidden getaway for bowhead whales in the Greenland Sea. Polar Biol 38:1315-1319

Christensen I, Haug T, Øien N (1992) Seasonal distribution, exploitation and present abundance of stocks of large baleen whales (Mysticeti) and sperm whales (Physeter macrocephalus) in Norwegian and adjacent waters. ICES J Mar Sci 49:341-355

Cooke JG, Reeves R (2018) Balaena mysticetus. The IUCN Red List of Threatened Species 2018:e.T2472 A50348144. www.iucnredlist.org/species/2472/50348144 (accessed 17 April 2019)

De Boer MN (2013) Elusive marine mammals exploredcharting under-recorded areas to study the abundance and distribution of cetaceans using multi-method approaches and platforms of opportunity. PhD dissertation, Wageningen University

* De Boer MN, Saulino JT, Van Waerebeek K, Aarts G (2016) Under pressure: cetaceans and fisheries co-occurrence off the coasts of Ghana and Côte d'Ivoire (Gulf of Guinea). Front Mar Sci 3:178

* De Boer MN, Jones D, Jones H (2017) Ocean wanderers: extralimital encounters with bowhead whales (Balaena mysticetus) in temperate European shallow waters. Aquat Mamm 43:279-288

*De Boer MN, Jones D, Jones H, Knee R (2018) Spatial and temporal baseline information on marine megafaunadata facilitated by a wildlife tour operator. Open J Mar Sci 8:76-113

Dyke AS, Hooper J, Savelle JM (1996) A history of sea ice in the Canadian Arctic Archipelago based on postglacial remains of the bowhead whale (Balaena mysticetus). Arctic 49:235-255

* Evans PGH, Hammond PS (2004) Monitoring cetaceans in European waters. Mammal Rev 34:131-156

Ferguson SH, Dueck L, Loseto LL, Luque SP (2010) Bowhead whale Balaena mysticetus seasonal selection of sea ice. Mar Ecol Prog Ser 411:285-297

* GEBCO (2014) Gridded bathymetry data. www.gebco.net/ data_and_products/gridded_bathymetry_data/ (accessed 25 August 2018)

*George JC, Zeh J, Suydam R, Clark C (2004) Abundance and population trend (1978-2001) of Western Arctic bowhead whales surveyed near Barrow, Alaska. Mar Mamm Sci 20:755-773

*George JC, Druckenmiller M, Laidre KL, Suydam R, Person B (2015) Western Arctic bowhead whale body condition and links to summer sea ice and upwelling in the Beaufort Sea. Prog Oceanogr 136: 250-262

Gilg O, Born EW (2005) Recent sightings of the bowhead whale (Balaena mysticetus) in Northeast Greenland and the Greenland Sea. Polar Biol 28:796-801

Hansen AS, Nielsen TG, Levinsen H, Madsen SD, Thingstad TF, Hansen BW (2003) Impact of changing ice cover on pelagic productivity and food web structure in Disko Bay, West Greenland: a dynamic model approach. Deep Sea Res I 50:171-187

*Heide-Jørgensen MP, Laidre KL, Wiig $\varnothing$, Jensen MV and others (2003) From Greenland to Canada in ten days: tracks of bowhead whales, Balaena mysticetus, across Baffin Bay. Arctic 56:21-31

*Heide-Jørgensen MP, Laidre KL, Borchers F, Samarra F, Stern H (2007) Increasing abundance of bowhead whales in West Greenland. Biol Lett 3:577-580 
Hunt GL Jr, Stabeno P, Walters G, Sinclair E, Brodeur RD, Napp JM, Bond NA (2002) Climate change and control of the southeastern Bering Sea pelagic ecosystem. Deep Sea Res II 49:5821-5853

Joiris C (2012) Possible impact of decreasing arctic pack ice on the higher trophic levels-seabirds and marine mammals. Adv Environ Res 23:207-221

Koski WR, Davis RA, Miller GW, Withrow DE (1993) Reproduction. In: Burns JJ, Montague JJ, Cowles CJ (eds) The bowhead whale. Special Publication No. 2. Society for Marine Mammalogy, Lawrence, KS, p 239-274

Kovacs KM, Biuw M, Nøst OA, Dodd P and others (2011) Seals used as 'research assistants' in the polar oceans. In: Orheim O, Ulstein $\mathrm{K}$ (eds) International polar year 2007-2008: the Norwegian contribution. Research Council of Norway, Oslo, p 100-103

Laidre KL, Stern H, Kovacs KM, Lowry L and others (2015) Arctic marine mammal population status, sea ice habitat loss, and conservation recommendations for the 21st century. Conserv Biol 29:724-737

Lydersen C, Freitas C, Wiig Ø, Bachmann L, Heide-Jørgensen MP, Swift R, Kovacs K (2012) Lost highway not forgotten: satellite tracking of a bowhead whale (Balaena mysticetus) from the Critically Endangered Spitsbergen stock. Arctic 65:76-86

Matthews CJD, Luque SP, Petersen SD, Andrews RD, Ferguson SH (2011) Satellite tracking of a killer whale (Orcinus orca) in the eastern Canadian Arctic documents ice avoidance and rapid, long-distance movement into the North Atlantic. Polar Biol 34:1091-1096

Miller CB (2003) Biological oceanography. Blackwell, Malden, MA

Moore SE (2016) Is it 'boom times' for baleen whales in the Pacific Arctic region? Biol Lett 12:20160251

Moore SE, Reeves RR (1993) Distribution and movement. In: Burns JJ, Montague JJ, Cowles CJ (eds) The bowhead whale. Special Publication No. 2. Society for Marine Mammalogy, Lawrence, KS, p 313-386

Editorial responsibility: Robert Harcourt, Sydney, New South Wales, Australia
Moore SE, Stafford KM, Melling H, Berchok C and others (2012) Comparing marine mammal acoustic habitats in Atlantic and Pacific sectors of the High Arctic: year-long records from Fram Strait and the Chukchi Plateau. Polar Biol 35:475-480

Norwegian Ice Service (2018) http://polarview.met.no/ (accessed 25 August 2018)

Ross WG (1993) Commercial whaling in the North Atlantic sector. In: Burns JJ, Montague JJ, Cowles CJ (eds) The bowhead whale. Special Publication No. 2. Society for Marine Mammalogy, Lawrence, KS, p 511-561

* Stafford KM, Moore SE, Berchok CL, Wiig $\varnothing$ and others (2012) Spitsbergen's endangered bowhead whales sing through the polar night. Endang Species Res 18: 95-103

* Stafford KM, Lydersen C, Wiig Ø, Kovacs KM (2018) Extreme diversity in the songs of Spitsbergen's bowhead whales. Biol Lett 14:20180056

*Vacquié-Garcia J, Lydersen C, Marques TA, Aars J and others (2017) Late summer distribution and abundance of ice-associated whales in the Norwegian High Arctic. Endang Species Res 32:59-70

Viddi FA, Hucke-Gaete R, Torres-Florez JP, Ribeiro S (2010) Spatial and seasonal variability in cetacean distribution in the fjords of northern Patagonia, Chile. ICES J Mar Sci 67:959-970

*Wiig Ø, Bachmann L, Janik VM, Kovacs KM, Lydersen C (2007) Spitsbergen bowhead whales revisited. Mar Mamm Sci 23:688-693

* Wiig Ø, Bachmann L, Øien N, Kovacs KM, Lydersen C (2010) Observations of bowhead whales (Balaena mysticetus) in the Svalbard area 1940-2009. Polar Biol 33: 979-984

Williams R (2003) Cetacean studies using platforms of opportunity. PhD dissertation, University of St. Andrews

Williams R, Hedley SL, Hammond PS (2006) Modelling distribution and abundance of Antarctic baleen whales using ships of opportunity. Ecol Soc 11:1-28

Submitted: November 21, 2018; Accepted: February 7, 2019 Proofs received from author(s): April 18, 2019 